\section{Potential Economic Impacts from Offshore Wind in the Gulf of Mexico Region}

Offshore wind is a clean, renewable source of energy and can be an economic driver in the United States. To better understand the employment opportunities and other potential regional economic impacts from offshore wind development, the U.S. Department of Energy (DOE) funded research that focuses on four regions of the country. The studies use multiple scenarios with various local job and domestic manufacturing content assumptions. Each regional study uses the new offshore wind Jobs and Economic Development Impacts (JEDI) model, developed by the National Renewable Energy Laboratory. This fact sheet summarizes the potential economic impacts for the Gulf of Mexico region.

\section{JEDI Models}

The JEDI models are spreadsheet-based tools that estimate the economic impacts of constructing and operating power plants, fuel-production facilities, and other projects. JEDI results are intended to be estimates given current specific conditions, not precise predictions. Based on user-entered, project-specific data or default inputs (derived from industry norms), JEDI models estimate the number of jobs and other economic impacts to an area (in this case, the Gulf of Mexico region) that can reasonably be supported by a new power plant, like an offshore wind facility. The JEDI models estimate gross impacts, as opposed to net, and are not a measure of project profitability or viability. JEDI presents results for jobs, earnings, and regional economic output, which are distributed across three categories:

- Project Development and Onsite Labor Impacts

- Local Revenue and Supply Chain Impacts

- Induced Impacts.
Economic multipliers contained within the model are derived from IMPLAN Group's IMpact analysis for PLANning (IMPLAN) accounting software. IMPLAN data sources include the Bureau of Labor Statistics, Bureau of Economic Analysis, and the U.S. Census.

Jobs are measured and reported as full-time equivalents (FTEs). One FTE represents one full-time worker who is employed for one year. Part-time and seasonal workers are a fraction of an FTE. The results of each offshore wind power scenario represent an estimate of the number of supply chain, construction, and operations-period jobs that could be supported in the Gulf of Mexico region.

\section{The Gulf of Mexico Region}

The Gulf of Mexico region is defined in this analysis as all U.S. states that surround the Gulf of Mexico: Texas, Louisiana, Mississippi, Alabama and Florida (Figure 1).

Offshore wind development and operation in the Gulf of Mexico are influenced by several unique factors:

- The offshore oil and gas industry has a significant amount of manufacturing infrastructure in the region that could quickly increase the percentage of total local content and decrease fabrication costs for offshore wind, particularly for foundations and substructures. The presence of skilled labor and equipment similar to those needed in the construction of offshore wind farms could contribute to lowering overall installation expenses.

- The Gulf's dense maritime infrastructure (e.g. ports and inland waterways) could lower operation and maintenance costs by reducing the distance that maintenance crews need to travel.

- State jurisdiction in Texas and the Gulf coast of Florida extends three times further from the coast than other U.S. coastal states. This has the potential of streamlining leasing processes by eliminating federal involvement in those two specific regions.

- The higher cost per kilowatt hour (kWh) of offshore wind as compared to other technologies is one of the biggest barriers for its deployment, according to a report by the Navigant Consortium. ${ }^{1}$ As of the time of this publication, Gulf Coast states have not implemented policies that could increase the competitiveness of offshore wind. Texas, the only Gulf Coast state with a Renewable Portfolio Standard (RPS), fulfilled its RPS obligations in 2009.

This study considered three offshore wind development scenarios examining different levels of capacity installed, regional supply chain development, and construction 
and operation costs. Offshore wind installations range from a low of 60 megawatts (MW) by 2020 to a high of 5,000 MW by 2030 (Table 1).

Investment in manufacturing and other important industries in the offshore wind supply chain within the Gulf of Mexico region would be needed before many of the materials needed to construct and operate an offshore wind plant could be purchased in the area. Such investment could be correlated with offshore wind deployment in the region, and regional offshore wind supply chain growth could put downward pressure on costs due to economies of scale and reduced transportation costs.

Table 1. Scenarios Modeled (2020 Value / 2030 Value) for Offshore Wind in the Gulf of Mexico Region

\begin{tabular}{|l|l|l|l|}
\multicolumn{5}{|c|}{ Inputs in years 2020/2030 } \\
\hline Scenario & $\begin{array}{l}\text { Cumulative } \\
\text { Capacity } \\
\text { Installed (MW) }\end{array}$ & $\begin{array}{l}\text { Supply Chain } \\
\text { Investment } \\
\text { (Local Content) }\end{array}$ & $\begin{array}{l}\text { Construction } \\
\text { Cost } \\
(\$ / \mathrm{kW})\end{array}$ \\
\hline Low & $60 / 1,000$ & $43 \% / 62 \%$ & $\$ 5,800 / \$ 4,930$ \\
\hline Moderate & $400 / 4,000$ & $49 \% / 73 \%$ & $\$ 5,400 / \$ 4,050$ \\
\hline High & $900 / 5,000$ & $55 \% / 81 \%$ & $\$ 5,220 / \$ 3,400$ \\
\hline
\end{tabular}

Table 2 shows assumptions for local content in major construction expenditures. Only 2030 values are shown. The scenarios assume that all operations and maintenance (O\&M) staff except for managers will be residents of the Gulf of Mexico region.

Table 2. 2030 Local Content of Select Expenditures during Construction

\begin{tabular}{|l|c|c|c|c|c|}
\hline Scenario & Blades & Towers & Nacelles & $\begin{array}{c}\text { Structure, } \\
\text { Foundation }\end{array}$ & Management \\
\hline Low & $15 \%$ & $35 \%$ & $0 \%$ & $100 \%$ & $70 \%$ \\
\hline Moderate & $55 \%$ & $65 \%$ & $20 \%$ & $100 \%$ & $90 \%$ \\
\hline High & $65 \%$ & $100 \%$ & $40 \%$ & $100 \%$ & $100 \%$ \\
\hline
\end{tabular}

The economic impact of a project varies according to the level of development and portion of expenditures made within the region. In the moderate scenario, construction is estimated to support approximately 5,120 total FTE jobs in 2020, and 17,280 in 2030. When O\&M jobs are included, the offshore wind industry in the Gulf of Mexico could support close to 22,500 FTE jobs in 2030. In average, approximately 11,950 total FTE jobs would be supported annually through 2030 in the moderate scenario (Table3 and Figure 2).

Jobs supported by offshore wind are expected to be well compensated, with average annual earnings (including benefits) of $\$ 139,000$ annually for onsite workers. Supply chain job holders are estimated to earn approximately $\$ 59,000$ and earnings from induced jobs are approximately $\$ 44,000$.

\section{Table 3: Jobs Supported by the Moderate Offshore Wind} Scenario for the Gulf of Mexico Region

\begin{tabular}{|l|r|r|}
\cline { 2 - 3 } \multicolumn{2}{l|}{} & Jobs (FTE) \\
2020 & $\begin{array}{r}\text { Jobs (FTE) } \\
2030\end{array}$ \\
\hline $\begin{array}{l}\text { Construction } \\
\text { Project Development and } \\
\text { Onsite Impacts }\end{array}$ & 1,340 & 4,800 \\
\hline $\begin{array}{l}\text { Construction and } \\
\text { Interconnection Labor }\end{array}$ & 1,180 & 4,440 \\
\hline \multicolumn{1}{|c|}{ Construction-Related Services } & 150 & 360 \\
\hline Turbine and Supply Chain Impacts & 2,000 & 6,580 \\
\hline Induced Impacts & 1,780 & 5,900 \\
\hline Total Construction Impacts & $\mathbf{5 , 1 2 0}$ & $\mathbf{1 7 , 2 8 0}$ \\
\hline Operations and Maintenance & 20 & 270 \\
\hline Onsite Labor Impacts & 310 & 3,140 \\
\hline Local Revenue and Supply & & 1,760 \\
\hline Chain Impacts & 170 & $\mathbf{5 , 1 7 0}$ \\
\hline Induced Impacts & $\mathbf{5 1 0}$ & \\
\hline Total O\&M Impacts & & \\
\hline
\end{tabular}

Totals may not sum due to rounding.

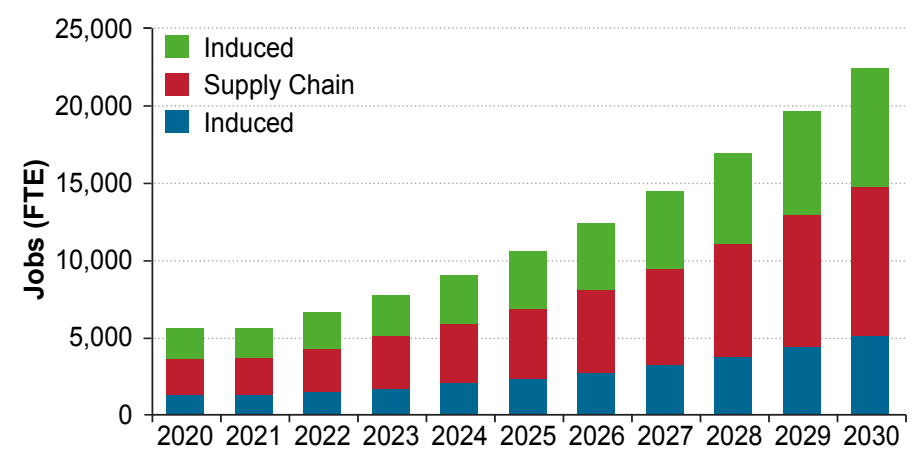

Figure 2. Estimated Number of Construction and O\&M Jobs Supported by Offshore Wind Deployment from 2020 to 2030 in the Gulf of Mexico region (Moderate Scenario)

The U.S. DOE Wind \& Water Power Technologies Office funded the National Renewable Energy Laboratory to perform this work under Contract DE-AC36-08GO28308.

For more information on DOE offshore wind work, please visit Offshore Wind Market Acceleration Projects at www.eere.energy.gov/wind/offshore_market_acceleration.html.
For more information, visit:

wind.energy.gov 